\title{
Disability management in the workplace: Problems and trends in Latvia
}

\author{
Zaiga Oborenko ${ }^{1, *}$, Marga Zivitere $^{2}$, and Elina Konstantinova ${ }^{2}$ \\ ${ }^{1}$ Latvia University of Agriculture, Latvia \\ ${ }^{2}$ Venstpils University College, Latvia
}

\begin{abstract}
People with disabilities are a largely untapped employment resource in many countries. About $48.5 \%$ of people with disabilities are employed in the European Union (EU), compared with only $24.4 \%$ in Latvia. Although there has been some progress on employing disabled people in Latvia, as the statistical facts and figures show, the problem still remains. This paper investigates how developing disability management in the workplace could open the possibilities for work for people with disabilities. It can be matched with the opportunities to increase the employment rate according to the European Disability Strategy (2010-2020) objectives, as well as fighting against social exclusion and allowing practical implementation of the United Convention on the rights of this group of people in Latvia. The aim of this research is to analyse the employment problems for people with disabilities and investigate disability management trends in Latvia. The main findings of this research are as follows: 1) people with disabilities are not considered as a prospective labour force by employers, 2) Latvian companies generally play a passive role in recruiting disabled people, especially those who have never had work experience with disabled people, 3) employers think that they do not receive state institutions' interest and support to encourage them to employ people with disabilities. The disability management is developing, although it shows quite slow movement in understanding people with disabilities as a valuable human resource.
\end{abstract}

Key words: ability to work, social inclusion, untapped employment resource, employers' attitude.

\section{Introduction}

People with disabilities are a largely untapped employment resource in many countries. At a European level, the employment rate of people with disabilities is about twenty-three percentage points lower compared to people without disabilities. About $48.5 \%$ of people with disabilities are employed compared to $71.4 \%$ of people without disabilities (data of 2013) [1]. At the European Union level, the employment rate of severely disabled people is $29 \%$, for people with a moderate disability, it is $56 \%$ and for non-disabled, it is $71 \%$ [1]. The situation across Member States differs significantly. The situation in the labour market for people with disabilities in Latvia is shown in Table 1 [2, 3]. From all the registered disabled people, 23.2\% are employed, whereas the employment rate among people aged $20-64$ reached $72.5 \%$ in 2015 [4].

\footnotetext{
* Corresponding author: zaiga. oborenko@gmail.com
} 
Table 1. People with disabilities and Latvian labour market at the end of 2015.

\begin{tabular}{|l|c|l|c|}
\hline $\begin{array}{l}\text { The number of people with } \\
\text { with disabilities (VDEĀVK) }\end{array}$ & $\mathbf{1 7 4 ~ 0 6 0}$ & $\begin{array}{l}\text { Percentage of all } \\
\text { population (CSP) }\end{array}$ & $\mathbf{8 . 6 4 \%}$ \\
\hline $\begin{array}{l}\text { The number of registered } \\
\text { unemployed people with disabilities (NVA) }\end{array}$ & $\mathbf{8 2 3 0}$ & $\begin{array}{l}\text { Percentage of all } \\
\text { unemployed (NVA) }\end{array}$ & $\mathbf{1 0 . 5 \%}$ \\
\hline $\begin{array}{l}\text { The number of employed people } \\
\text { people with disabilities (VSAA) }\end{array}$ & $\mathbf{4 0 ~ 4 5 0}$ & $\begin{array}{l}\text { Percentage of all employed } \\
\text { (VSAA/CSP) }\end{array}$ & $\begin{array}{l}\mathbf{4 . 5 \%} \\
\mathbf{4 . 5 \%}\end{array}$ \\
\hline
\end{tabular}

Sources: Ministry of Welfare of Latvia, Central Statistical Bureau of Latvia (CSP), The State Employment Agency (NVA), The State Social Insurance Agency (VSAA), The State Medical Commission for the Assessment of Health Condition and Working Ability (VDEAVK).

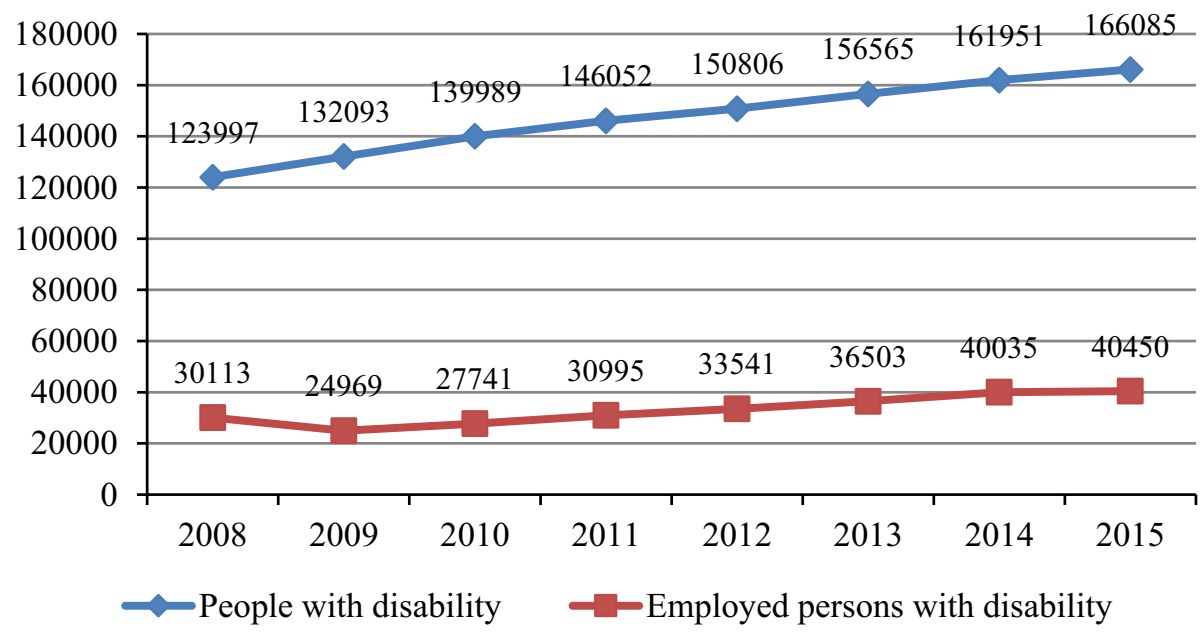

Fig. 1. The number of people with disabilities and employed people with disabilities, 2008-2015. Source: The State Social Insurance Agency (VSAA).

As the statistical facts and figures show, there is a problem of inadequate employment among people with disabilities in Latvia (Fig. 1) [5].

As can be observed from Fig. 1 and Fig. 2, the amount of people with disabilities tends to grow significantly but, as to the amount of employed disabled people, growth is very slow and has almost remained at the same level during the last two years [5].

In this context, the unemployment level at the end of 2016 in Latvia was 6.5\%, 78357 people were unemployed; 9441 were people with disabilities which makes them $12 \%$ of all the unemployed [6]. The situation of people with disabilities shows the difficulties they encounter when trying to enter the labour market. In addition, the Labour Law restrictions on the job contract may affect employers' choice not to recruit people with disabilities, because if the person is recognised as a disabled person, an employer has limited possibilities for terminating the contract [7]. At the same time, it is important to draw attention to the fact that the rise in unemployment is also related to the activities of disabled people. Widely available information for people with disabilities, as well as employers, gives new opportunities for training and employment services and, consequently, people with disabilities have an interest to register and participate in the State Employment Agency activities.

Latvia's at-risk-of-poverty and social exclusion rate is among the highest in the EU. The coverage of activation measures remains low, particularly for the long-term unemployed. The 


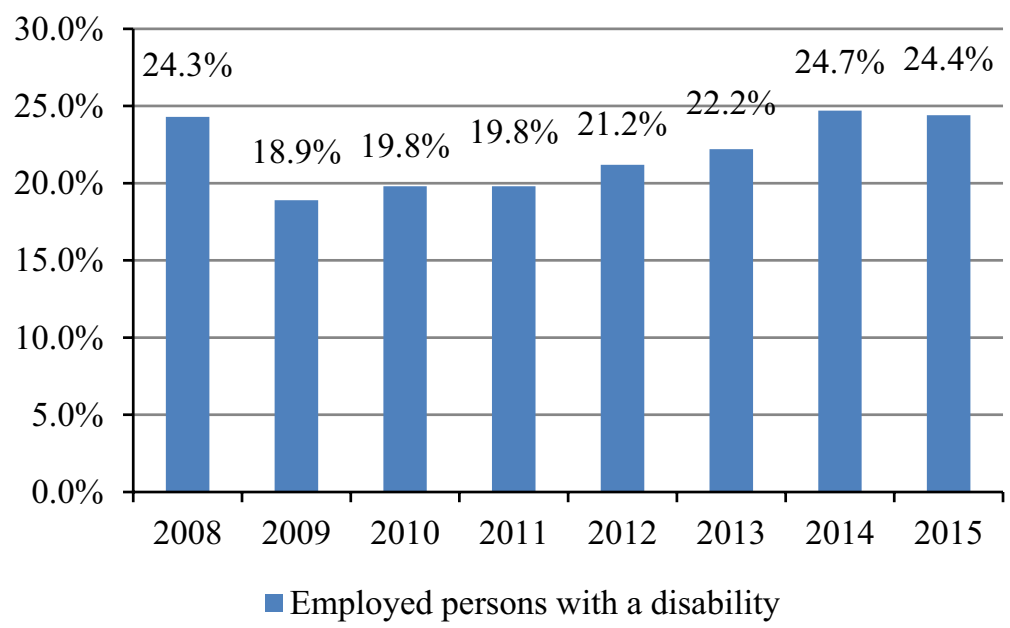

Fig. 2. Employed people with disabilities as a proportion of the total number of people with disabilities, 2008-2015. Source: TheState Social Insurance Agency (VSAA).

combination of poor health and insufficient social services hampers effective reintegration in the labour market. The Academic Network of European Network Disability experts admits that there has been some progress on the employment of disabled people but recommends key points for Latvia - to improve employability and vocational education and training for people with disabilities [8].

During the last decade, the disability policy at the European level has changed from a formerly disregarded branch of traditional social policy into a modern policy formation, which comprises not only social protection and labour market integration, but also equal rights and non-discrimination [9]. Disability policy implies, on the one hand, a set of traditional social policy measures such as programmes for social protection and labour market integration. On the other hand, it is part of the non-discrimination policy as well. Together with gender, ethnic origin, religion or belief, age and sexual orientation, disability is covered by the equal rights legislation of the European Union [10]. Although there are no available statistics to prove discrimination cases, according to the study which surveyed Latvian citizens, $50 \%$ of respondents believe that discrimination on grounds of disability is relatively common in Latvia [11]. It is found that employers do not have any understanding about disability, its consequences and the restrictions on people with disabilities in life and job opportunities that hinder them from having effective participation in the labour market [12]. Social entrepreneurship can be mentioned as one of the possible mechanisms of support and integration for people with disabilities and other disadvantaged social groups. Its principal objective is for important communal social problem solving using business methods. Such business development also contributes to employment, including helping disadvantaged people into the labour market, thereby reducing poverty and social exclusion. Work on this form of entrepreneurship development is continuing at both the Latvian and the EU level.

Authors of this paper are concerned about how developing disability management in the workplace could open the possibilities for work for disabled people. It can be matched with the opportunities of increasing the employment rate according to the European Disability Strategy (2010-2020) objectives [13], as well as with fighting against social exclusion and implementation of the United Convention on the rights of this group of people in Latvia [14]. In 2013 the Ministry of Welfare worked out strategic guidelines and planning documents for implementing the Convention on the rights of people with disabilities for the years 
2014-2020 [15]. Documents do exist, but how effective they are and how they match employers' motivation to recruit disabled people makes one of the research questions. There are specific situations of disability management in the workplace in Latvia compared with Old Europe; partly it is influenced by the heritage from the past - the Soviet system, economic, legal, social and psychological issues, which add up to a complexity of barriers for this group of people.

Aim and tasks of the study. The study question of this paper is what kind of trends in employment of people with disabilities can be observed. The aim of this research is to analyse the problems for employing people with disabilities and investigate employment trends for disabled people in Latvia. The following tasks are set up: 1) to study employers' attitudes towards the employment of people with disabilities in Latvia and 2) to find out the reasons for the low employment rate of people with disabilities. Research focused on the employers' demands to determine the professions and special skills required for people with severe disabilities.

Research methods. Authors used descriptive and analytical research of secondary resources. An employers' survey was used as a primary method - questionnaire and interviews. The employers' survey was done in June 2016 by KPMG (Klynveld, Peat, Marwick \& Goerdeler), Baltic on the request of The Social Integration State Agency [16]. One of the authors of this paper participated in this research team. Employers were reached through the following organisations representing employers: the Latvian Chamber of Commerce and Industry which unites one thousand three hundred and sixty-seven companies, forty-seven industry associations, nine city business clubs, and eleven other businessmen's unions, the Employers' Confederation of Latvia which unites and represents five thousand companies, sixty-six sector-based and regional business associations and federations, the Civic Alliance, Latvia which unites one hundred and thirty-five members from the NGO sector, the Latvian Association of Local and Regional Governments and the Foreign Investors' Council in Latvia.

Disability management in the workplace has been given rather limited research attention. The question for further discussion of this study is: how to arouse the interest of employers to employ people with disabilities.

\section{Results}

\subsection{Experience of employing people with disabilities}

According to the results of research carried out within the framework of the Leonardo da Vinc $i$ project "Ability not Disability in the Workplace" [17] in 2011, Latvian companies generally play a passive role in recruiting people with disabilities, especially those who have never considered hiring a disabled person. They believe that Latvian public associations and foundations should be the first ones to offer disabled people a job option [17].

In 2014 the survey of the Latvian Association for People Management (LAPM) members showed that more than half of companies (55\%) are currently employing people with disabilities, $16 \%$ used to employ disabled people previously and $27 \%$ had no experience of employing people with disabilities [18]. The Latvian Association for People Management connects human resource professionals from two hundred and twenty organisations.

In contrast, the survey, done by KPMG Baltics in 2016 [16], showed a different picture: $63 \%$ of all employers had never employed people with disabilities, $32 \%$ had employed people with disabilities and $4 \%$ had experienced employing people with mental disorders.

Different results of surveys can be explained by different samples. Undeniably, not only the size of the samples but also respondents' qualifications influenced the results. Human 


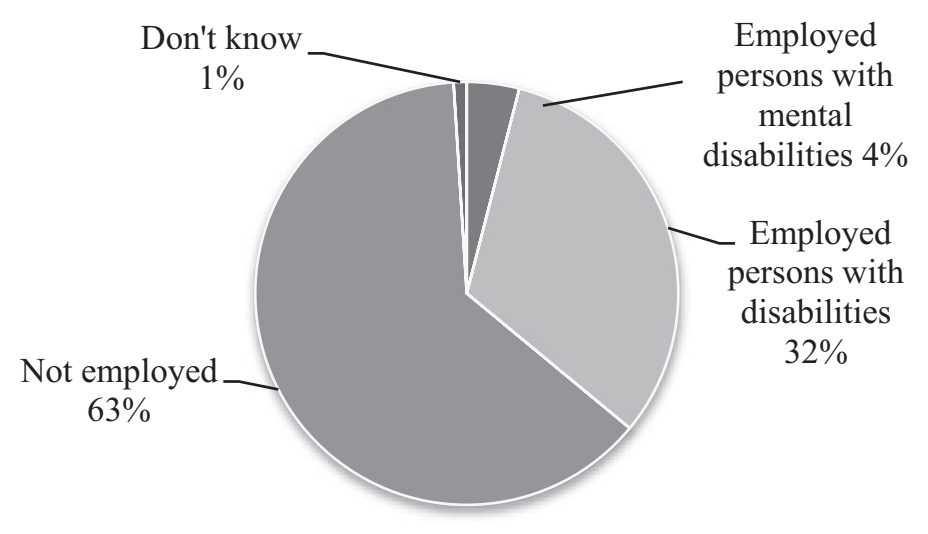

Fig. 3. Experience of employers of hiring disabled people within the last 3 years, 2016. Source: KPMG Baltics "Labour market demand study to employ people with significant disabilities and mental disorders", The Social Integration State Agency.

resource professionals from LAPM, representing the company strategic approach to human resources, made an impact on these significant differences. The LAPM survey cannot represent the situation of all Latvian companies, but it shows how big differences exist in the experience of employing people with disabilities.

A company operates not only within markets, but also within a society. Interactions among business, government and society are infinite and their meaning is open to interpretation [8-19]. It is possible to single out four simple mental models: the market capitalism model, the dominance model, the countervailing forces model and the stakeholder model [ibid]. Depending on the model used, a person will think differently about the scope of business power in society, the criteria for managerial decisions, the extent of corporate responsibility, the ethical duties of managers and the need for regulation [ibid]. Characteristics of these models are included in Table 2. Although these models have been developed historically, they all co-exist in modern times in different societies. In each of these models, different disability management can be applied.

Whichever model of the business-government-society relationship one might find compelling, it is clear that businesses operate in the dynamic environment comprised of several specific environments such as legal, governmental, cultural, natural, technological and economic and is influenced by them. The role of governments is not only to encourage and constrain businesses but also to ensure that society will not abandon those who fail.

A very important factor that makes a negative impact on social policy is the shadow economy in Latvia. The shadow economy index was $21.3 \%$ in 2015 . The index measures the size of the shadow economy as a percentage of GDP; it combines estimates of misreported business income, unregistered or hidden employees, as well as unreported "envelope" wages. The largest component of the shadow economy in Latvia is unreported business income (44.4\%), followed by envelope wages (34.9\%) and then unreported or unregistered employees (20.7\%) [20]. Companies which do not pay all their taxes, illegally pay salaries and hide revenues probably do not hire people with disabilities and certainly do not make a supportive work place environment for disabled people.

Employers should be aware that the Latvian workforce is aging as it was reported by the Cabinet of Ministers [21] and OECD [22], and that they will face the fact of disability more and more. A significant proportion of people are affected by disability at some point during their working lives. Marketing and public opinion research centre SKDS in the survey of 


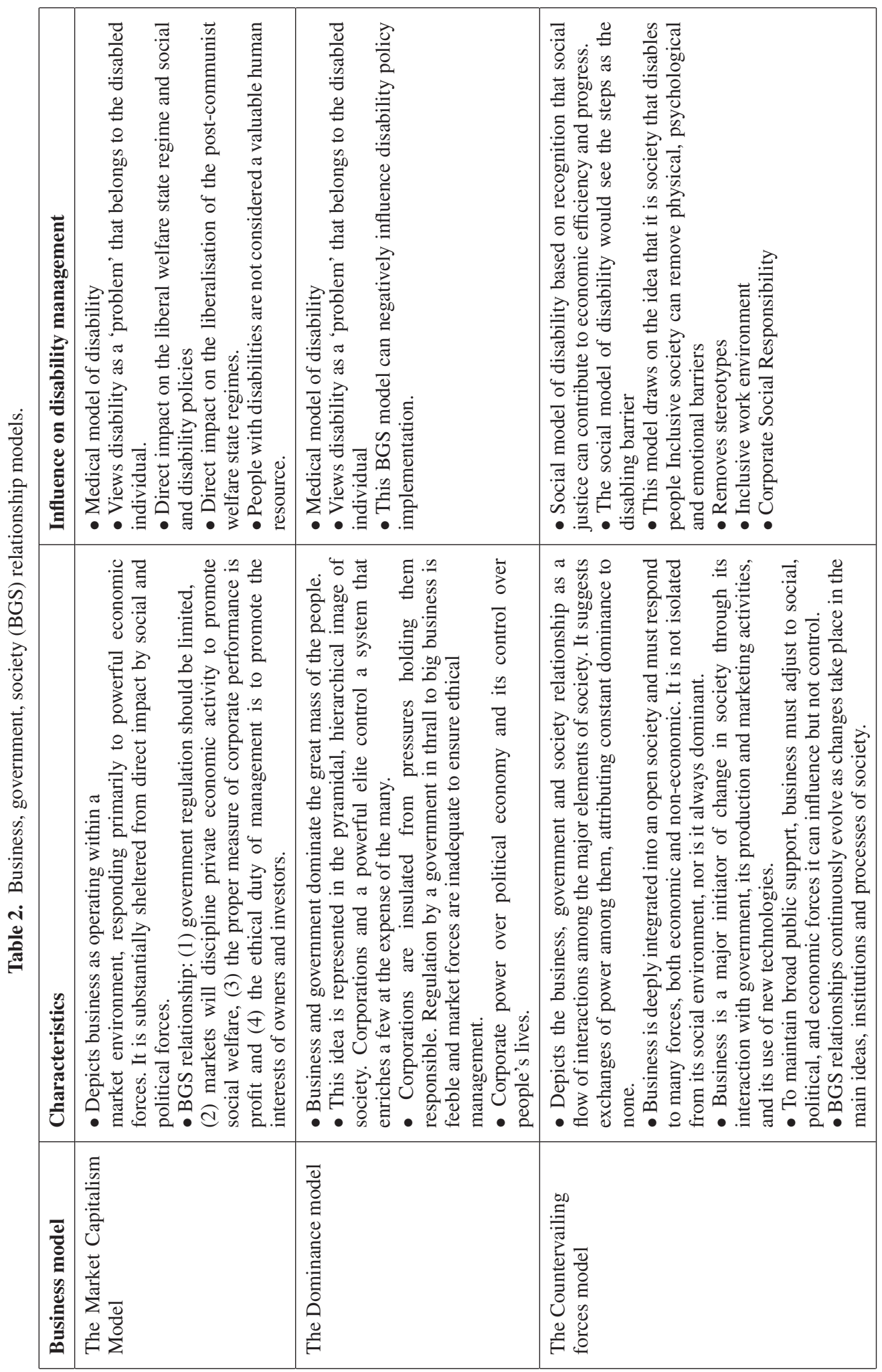




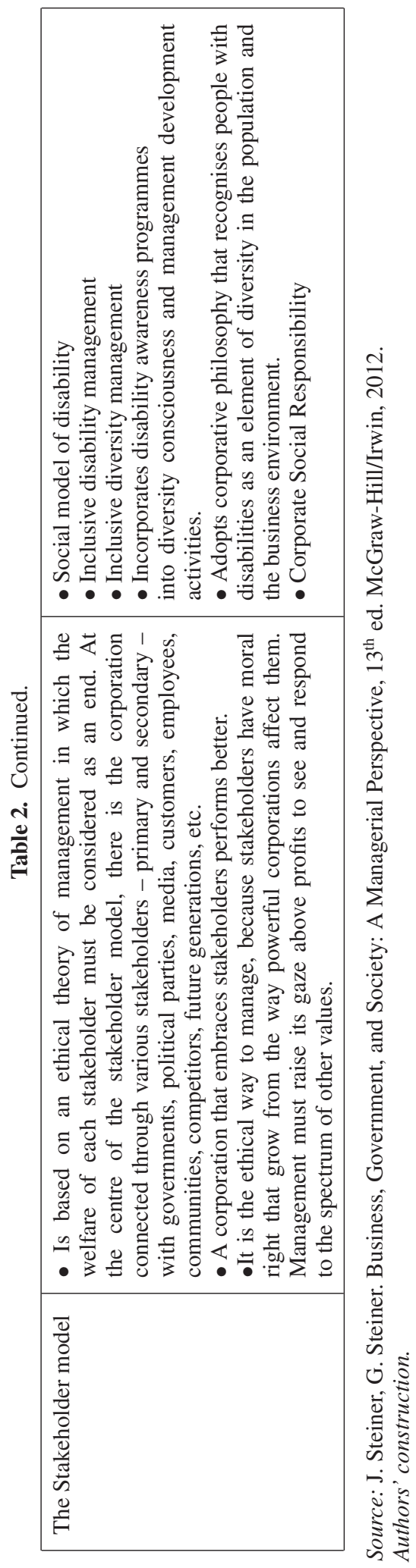




\section{Would you consider hiring persons with disability or mental disorders?}

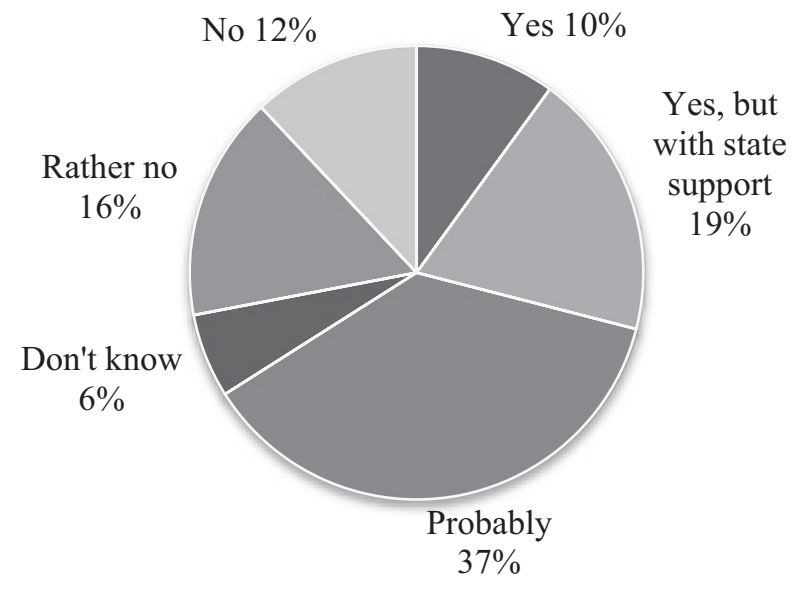

Fig. 4. Would you consider hiring people with disabilities or mental disorders? Source: KPMG Baltics "Labour market demand study to employ people with significant disabilities and mental disorders", The Social Integration State Agency.

the Latvian Association for People Management found that in 39\% of the companies there has been at least one case when an employee, during his or her employment period, has acquired a disability. A half of those $-50 \%$ of the employees - acquired heart and vascular diseases, haemophilia, HIV, tumours, etc., while $31 \%$ acquired movement disorders. $76 \%$ of these employees returned to the company after the state of health had improved [18]. People with disabilities are the only minority that any person can join at any time [23]; and two populations the "disabled" and "the non-disabled" are fluid rather than fixed [24], therefore, companies should take care of the health issues of their employees and that should be a part of disability management.

\subsection{Willingness to employ people with disabilities}

The research shows (Fig. 4) that only $10 \%$ of organisations indicated their willingness to employ people with disabilities, $19 \%$ would employ with state support, but $37 \%$ of respondents were indecisive and their answer is probably, $28 \%$ of respondents who answered negatively ("no" and "rather no" included).

As stated in the EU2020 strategy, people with disabilities are included in national level policy planning papers although concrete measures regarding them are not provided. Concerning measures included in the National Reform Programme, all issues to be developed between 2014 and 2020 and the Partnership Agreement are in compliance with the promotion of, and access to, employment, education and social inclusion for people with disabilities. According to the state programme employers can receive financial support within subsidised employment measures. As reported in the European Semester 2015/2016 country fiche on disability, the number of employed in subsidised working places was four hundred and ninetyseven in 2012 and it is planned to be seven hundred in 2017 [3]. The financial support is provided for twenty-four months, after that period that employer can decide to hire the disabled person or not. As statistics show, $67 \%$ of people with disabilities, after participation in special programmes, got a permanent job placement [25]. 
Table 3. Factors which discourage employers from hiring disabled people.

\begin{tabular}{|l|l|}
\hline 1) & People with disabilities attitude to work \\
\hline 2) & Lack of suitable qualifications, knowledge and skills \\
\hline 3) & Concerns with problems linked to lost working capacity. Work abilities - quality and speed \\
\hline 4) & Ability to solve problems independently, notablyfor a disabled person with mental disorders \\
\hline 5) & The need to adapt the workplace and time needed to support disabled people \\
\hline 6) & Need for technical aids and adjustments in the work place, need for part-time jobs \\
\hline 7) & Lack of competence to employ people with disabilities \\
\hline 8) & Do not have a suitable vacancy because of industry specifics \\
\hline 9) & $\begin{array}{l}\text { Concerns with health and safety aspects. Will there be more work accidents? Does it mean } \\
\text { higher absenteeism? }\end{array}$ \\
\hline 10) & No willingness to hire disabled people with mental disorders \\
\hline 11) & Public stereotypes and prejudices \\
\hline 12) & Concerns with regard to social interaction, fear that co-workers will react negatively \\
\hline 13) & $\begin{array}{l}\text { Lack of financial information and educational support from the state. Specially educated } \\
\text { and trained support person needed }\end{array}$ \\
\hline 14) & Not stimulating legislation \\
\hline
\end{tabular}

Sources: KPMG Baltics "Labour market demand study to employ people with significant disabilities and mental disorders", 2016 [16], and Leonardo da Vinci "Ability no Disability in workplace”, 2011 [17]. Authors' construction.

According to KPMG Baltics survey [16], 68\% of employers indicated that they had not been informed about subsidised employment measures, $27 \%$ indicated that they had been informed, but only $5 \%$ of respondents pointed out that they were informed and that they use this state supported programme. The survey data shows evidence that there is a lack of cooperation between the state and employers.

The employer's ability to adapt the workplace for people with disabilities is as follows: $45 \%$ of employers indicated that they are able to adapt the workplace for disabled employees, $37 \%$ said they can but with state support, only $18 \%$ indicated they cannot adapt the workplace [ibid].

For better understanding of the employers' attitudes, it is helpful to explore what factors discourage the hiring of people with disabilities. The main reasons are summarised in Table 3.

As the main obstacles to employing people with disabilities, employers pointed out 1) shortage of skills that negatively may affect the quality of work and productivity, 2) ability to solve problems independently, 3) lack of stimulating legislation, 4) lack of state support and adjustment for the workplace.

Other research results in different countries show quite a similar picture [26, 27]. The point of the study of different experiences in other countries is better to understand the strategies needed to be implemented in order to reach the employment goals for people with disabilities in Latvia.

\section{Conclusions}

Despite state plans for programmes and measures to involve people with disabilities in the labour market, results show very slow improvement. In general,the State Employment 
Agency's subsidised workplace programme is a good initiative, which helps to integrate into the labour market people with disabilities. The problem with a subsidised workplace is that it is terminated.

The economic, social and legislation environment for businesses makes very weak motivation to work in a socially responsible way and hire and retain disabled people. The work environment for people with disabilities is favourable in those companies with high corporate values and culture, who have diversity management and disability management as strategies for human resources, who have developed corporate social responsibility strategies. It very much depends on how companies see the business - government - society relationship, the way the businesses reach their goals.

Unfortunately, Latvian companies generally play a passive role in recruiting disabled people, especially those that have never hired a disabled person. At present, employers are not interested in employing people with mental disorders (only 17\% would delegate business functions). The reasons for avoiding employment of people of disabilities could be that the employer does not know how to work with this type of employee. According to the survey results, only $5 \%$ of employers have had experience of employing a person with mental disabilities. Another reason - the organisation does not have the functions of the delegate. According to the current understanding and without any additional education, employers are not able to determine precisely the areas in which they can delegate business functions to disabled people.

Employers are not ready for the work process redesign and they do not see distance work as a good option for employing disabled people.

Barriers and prejudices are alive in society. State institutions have to implement informative and educational activities to change the attitudes of employers and the public.

The appropriate changes in labour legislation are needed in order to serve both the employer's and the employee's interests. The law of Social Entrepreneurshipis being developed. There might be new vacancies directly to the target groupwho employ people with disabilities, so state institutions' cooperation with social entrepreneurs should be developed.

Theoretical and practical training for employers can be seen as one of the crucial elements in the employment of people with disabilties. There are no professional standards for Managers and Human Resource managers on how to recruit, retain and work with disabled people.

The authors wish to thank KPMG Baltics and the Social Integration State Agency for support and permission to use unpublished research results.

\section{References}

[1] European comparative data on Europe 2020 \& People with disabilities (2015), available: http://www.disability-europe.net/search? searchword=employ ment\&searchphrase=all

[2] Ministry of Welfare (2016). Current activities for promotion of employment of people with disabilities in Latvia. In: Conference The Opportunities and Challenges of Rehabilitation and Employability of People with Disabilities in Latvia and Europe. Retrieved from http://saeima.lv/lv/aktualitates/saeimas-zinas/24961saeima-diskute-par-darba-tirgus-pieejamibu-cilvekiem-arinvaliditati

[3] European Semester 2015/2016 country fiche on disability: Latvia report, available http://www.disability-europe.net/search?searchword=employment\& searchphrase=all\&areas []$=$ documents_search\&areas []$=42$ 
[4] Central Statistical Bureau of Latvia (CSP). Labour Force Survey: Key Indicators in 2015. Available: http://www.csb.gov.lv/sites/default/files/nr_17_ darbaspeka_apsekojuma_galvenie_raditaji_2015_gada_16_00_lv_en.pdf

[5] State Social Insurance Agency (VSAA). http://www.vsaa.1v/lv/budzetsun-statistika/statistika

[6] State Employment Agency (NVA). Available http://www.nva.gov.lv/index. php?cid=6http:

[7] Parliament of Latvia. Labour Law, https://likumi.lv/doc.php?id=26019

[8] European Semester 2015/2016 fiche on disability: European Union overview. (2016), available http://www.disability-europe.net/search?searchword= employment\&searchphrase $=a l l$

[9] A. Waldschmidt, ALTER, Eur. J. Disability Res. 3, 8-23 (2009)

[10] European Union Legislation. http://ec.europa.eu/justice/discrimination/ law/index_en.htm

[11] EU. Special Eurobarometer 393. Discrimination in the EU in 2012. http://ec.europa.eu/public_opinion/archives/ebs/ebs_393_en.pdf

[12] Cabinet of Ministers. United Nations Convention on Persons with Disabilities implementation guidelines 2014-2020 (2013). https://likumi.lv/ta/id/273969par-ieklaujosas-nodarbinatibas-pamatnostadnem-2015-2020-gadam

[13] European Commission (Brussels, 15.11.2010 COM (2010) 636 final). European Disability Strategy 2010-2020: A Renewed Commitment to a Barrier-Free Europe (Communication from the Commission to the European Parliament, the Council, the European Economic and Social Committee and the Committee of the Regions). Retrieved January 27, 2011 (p. 11), http://eur-lex. europa. eu

[14] Parliament of Latvia. Convention on the Rights of Persons with Disabilities, available: https://likumi.lv/legislation/en/en/treaties/id/1630-convention-on -the-rights-of-persons-with-disabilities

[15] Ministry of Welfare. Latvian policy planning documents. http://www.Im.gov.Iv/ text/3462

[16] KPMG Baltics, Social Integration State Agency (2016). Labour market demand study to employ people with severe disabilities and mental disorders, unpublished

[17] Leonardo da Vinci project "Ability not Disability in Workplace" (2011). Available http://www . andiw.isma.lv/

[18] SKDS (2014). Latvijas иzn̄ēmuти pieredze personu ar invaliditāti nodarbināšanā. Latvijas Personāla vadī̌̌anas asociācijas biedru aptauja (Latvian business experience in the employment of persons with disabilities. Latvian Association for People Management members survey), unpublished

[19] J. Steiner, G. Steiner, Business, Government, and Society: A Managerial Perspective, $13^{\text {th }}$ edn. (McGraw-Hill/Irwin, 2012)

[20] T. Putnins, A. Sauka, Shadow Economy Index for the Baltic Countries 2009-2015 (Stockholm School of Economics in Riga, 2016)

[21] Cabinet of Ministers. Ministru kabineta rikojums Nr. 507 (2016). Par konceptualo zinojumu "Aktivas novecosanas strategija ilgakam un labakam darba muzam Latvija" (About the conceptual report "Strategy of active aging for a longer and better working life in Latvia"). Retrieved from http://likumi . lv/doc . php?id=284635

[22] OECD (Organisation for Economic Co-operation and Development) (2010). Sickness, Disability and Work breaking the barriers: A synthesis of findings across OECD countries. Retrieved from http://www.oecd-ilibrary.org/ social-issues-migration-health/sickness-disability-and-workbreaking-the-barriers/foreword_9789264088856-1-en 
[23] R. Ledman, D. Brown, D, SAM Adv. Manage. J. Spring, 17-20 (1993). Retrieved from http://www.freepatentsonline.com/article/SAM-Advanced-ManagementJournal/14467429.html [accessed 26 Dec. 2016]

[24] D. Halabisky (2014), Entrepreneurial Activities in EuropeEntrepreneurship for People with Disabilities, OECD Employment Policy Papers, No. 6, OECD. Publishing, Paris. Retrieved from http://www . oecd-ilibrary . org/ employment/entrepreneurial-activities-in-europe-entrepreneurshipfor-people-with-disabilities_5jxrcmkcxjq4-en

[25] State Employment Agency support unemployed persons with disabilities (2016). Available: http://m.nva.gov.lv/LV/aktuala_informacija/aktualitates/ 4377nva_atbalsts_bezdarbniekiem_ar_invaliditati.html

[26] M. Lengnick-Hall, P. Gaunt, A. Brooks, Why Employers Don't Hire People With Disabilities: A Survey of the Literature. Available http://www.cprf.org/ studies/why-employers-dont-hire-people-with-disabilities-a-surveyof-the-literature/

[27] H.S. Kaye, L.H. Jans, E.C. Jones, J. Occup. Rehabilitation 21(4), 526-536 (2011) https://www.ncbi.nlm.nih.gov/pmc/articles/PMC3217147/ 